\title{
Contents, Vol. 34, 1990
}

European Journal of Nutrition, Metabolic Diseases and Dietetics

Journal européen de nutrition, des maladies métaboliques et de diététique

$1 \Omega O \cap$ Europäische Zeitschnft für Ernährungswissenschaft, Stoffwechselstörungen

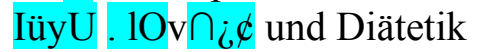

Official Journal of the Federation of European Nutrition Societies

lyyw Annals of Nutrition and Metabolism (formerly 'Annales de la Nutrition et $<\mathrm{F}$ de $\Gamma$ Alimentation' and 'Nutrition and Metabolism') is recognised by the

'Federation of European Nutrition Societies' (FENS) as its official journal Founded 1959 as 'Nutritio et Dieta by E. Azerad, H. Kapp and J. Trémolières

Former Main Editor: A. Wretlind (1961-1969)

Continued as 'Nutrition and Metabolism' (1970-1980)

Since 1980 integrating 'Annales de la Nutrition et de $\Gamma$ Alimentation'

Senior Editor Editorial Board

N. Zöllner, München L.G. Alcindor, Paris B. Jacotot, Créteil

Main Editors

G. Wolfram, Freising C Barth, Kiel I. Macdonald, London

B. Brubacher, Basel C.F. Mills, Aberdeen

J.W.T. Dickerson, Guildford D.J. Naismith, London

Associate Editor F. Falkner, Berkeley, Calif. K.R. Norum, Oslo

G. Debry, Nancy Ch. Frayssinet, Villejuif G. Schlierf, Heidelberg

J. Marks, Cambridge P. Fürst, Stuttgart/Hohenheim M.A. Spadoni, Roma

L. Gueguen, Jouy-en-Josas A.J. Vergroesen, Mariapfarr

L. Hambraeus, Uppsala W. Waldhäusl, Wien

K. Hellström, Stockholm A. Wretlind, Stockholm

F.A. Hommes, Augusta, Ga.

Advisory Board, FENS

Austria H. Zucker†, München

B.M. Brandstetter, Wien Netherlands

Bulgaria R.J.J. Hermus, Boven-Leeuwen

L. Balabanski, Sofia Norway

Denmark K.R. Norum, Oslo

E. Aaes-Jørgensen, København Poland

East Germany S. Berger, Warzawa

H. Schmandke, Spain

Bergholz-Rehbrücke G. Varela, Madrid

Finland Sweden 
H. Koskinen, Helsinki L. Hambraeus, Uppsala

Great Britain Switzerland

J. Dickerson, Guildford E. Jéquier, Lausanne

Greece West Germany

A. Trichopoulou, Athens

Italy

E. Lanzola, Pavia G. Schlierf, Heidelberg

\section{KAHGEfc}

S. Karger - Medical and Scientific Publishers

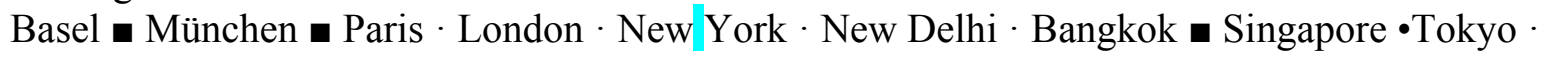

Sydney

Drug Dosage

The authors and the publisher have exerted every effort to ensure that drug selection and dosage set forth in this text are in accord with current recommendations and practice at the time of publication. However, in view of ongoing research, changes in government regulations, and the constant flow of information relating to drug therapy and drug reactions, the reader is urged to check the package insert for each drug for any change in indications and dosage and for added warnings and precautions. This is particularly important when the recommended agent is a new and/or infrequently employed drug.

All rights reserved.

No part of this publication may be translated into other languages, reproduced or utilized in any form or by any means, electronic or mechanical, including photocopying, recording, microcopying, or by any information storage and retrieval system, without permission in writing from the publisher or, in the case of photocopying, direct payment of a specified fee to the Copyright Clearance Center (see 'Information for Readers and Subscribers').

(C) Copyright 1990 by

S. Karger AG, P.O. Box, CH-4009 Basel (Switzerland) Printed in Switzerland by Thür AG Offsetdruck, Pratteln

Contents Vol. 34,1990

No. 1 Original Paper

Effect of Prolonged Galactose Consumption on Galactose Tolerance in Young Healthy Humans

Birlouez-Aragon, I.; Alloussi, S 1

Possible Role of Thyroid Hormone in Decreased Somatomedin-C Levels in Diabetic and Starved Rats

Ikeda, T.; Fujiyama, K.; Hoshino, T.; Takeuchi, T.; Mashiba, H.; Tominaga, M. . . 8 Chain Elongation of Fatty Acids in Rat Small Intestine: Subcellular Localization and Effects of Clofibrate and Partially Hydrogenated Fish Oil

Thomassen, M.S.; Rørtveit, T.; Nilsson, A.; Prydz, K.; Christiansen, E.N 13

Effect of Undernutrition on the Immune Response to Rotavirus Infection in Mice

Ahmed, F.; Jones, D.B.; Jackson, A.A 21

Effect of Ascorbic Acid Supplementation on Haematological Response and Ascorbic Acid Status of Young Female Adults

Ajayi, O.A.; Nnaji, U.R 32 
Effect of Sampling Site on Retinol, Carotenoid, Tocopherol, and Tocotrienol Concentration of Adipose Tissue of Human Breast with Cancer

Rautalahti, M.; Albanes, D.; Hyvönen, L.; Piironen, V.; Heinonen, M 37

Influence of Kinetics of Gastric Emptying on Hepatic IGF1 Production in Young Calves

Coxam, V.; Davicco, M.-J.; Durand, D.; Bauchart, D.; Opmeer, F.; Barlet, J.-P. ... 42

Abstracts

Third Créteil Symposium on Lipids, Lipoproteins and Nutrition. Nutrition and Dyslipoproteinemia

Créteil, France, March 17, $1989 \quad 53$

No. 2 Original Paper

Estimation de la consommation moyenne de fibres alimentaires en France (Evaluation of Average Daily Consumption of Dietary Fiber in France)

Bagheri, S.M.; Debry, G 69

Augmentation of Mouse Immune Functions by Dietary Restriction: An Investigation up to 1 Year of Age

Hishinuma, K.; Nishimura, T.; Konno, A.; Hashimoto, Y.; Kimura, S 76

Plasma Cortisol and Adrenal Ascorbic Acid Levels after ACTH Treatment with a High

Intake of Ascorbic Acid in the Guinea Pig

Laney, P.H.; Levy, J.A.; Kipp, D.E 85

Excess Dietary Methionine Decreases Indices of Copper Status in the Rat

Strain, J.J.; Lynch, S.M 93

Intermediate Density Lipoprotein-Apolipoprotein B Turnover in Rabbits Fed Semipurified Diets Containing Casein or Soy Protein

Samman, S.; Khosla, P.; Carroll, K.K 98

IV Contents

Comparative Studies on the Effect of Vitamin A, Bl, and B6 Deficiency on Oxalate Metab olism in Male Rats

Sharma, S.; Sidhu, H.; Narula, R.; Thind, S.K.; Nath, R 104

Comparison of a Face-Mask and a Mouthpiece for Measuring Resting Energy Expenditure with the 'Oxylog'

Bukkens, S.G.F.; McNeill, G 112

Kinetics and Balance of Glucose and Galactose Appearance in the Portal Blood after Intake of Lactose or Hydrolysed Lactose in Conscious Pigs

Rérat, A.; Vaissade, P.; Vaugelade, P119

No. 3 Original Paper

Effects of a Short-Term (4 Weeks) Protein-Sparing Modified Fast on Plasma Lipids and Lipoproteins in Obese Women

Vermeulen, A 133

Effect of Vitamin E Deficiency on Oxidative Metabolism and Antioxidant Enzyme Activity of Macrophages

Sharmanov, A.T.; Aidarkhanov, B.B.; Kurmangalinov, S.M143

Effects of Defective in vivo Synthesis of Mitochondrial Proteins on Cellular Biochemistry and Physiology of Malnourished Rats

Olowookere, J.O.; Olorunsogo, O.O.; Malomo, S.0 147

Effect of Malnutrition and Hormone Treatments on Intestinal Microvillus Membrane Glycosylation in Suckling Rats 
Jaswal, V.M.S.; Babbar, H.S.; Mahmood, A 155

Effects of Meal Size Reduction on Postprandial Variables in Male Volunteers

Amelsvoort, J.M.M. van; Stratum, P. van; Dubbelman, G.P.; Lussenburg, R.N. ... 163 Nutritional

Value and Intestinal Effects of Dipeptides and Tripeptides. Comparison with

Their Issuing Bovine Plasma Protein in Rats

Rouanet, J.M.; Zambonino Infante, J.L.; Caporiccio, B.; Pejoan, C 175

Effects of Dietary Magnesium and/or Manganese Variables on the Growth Rate and Metabolism of Mice

Fahim, F.A.; Morcos, N.Y.S.; Esmat, A.Y 183

No. 4 Original Paper

Increased Myocardial and Hepatic Iron Concentration in Pigs with Microangiopathy (Mulberry

Heart Disease) as a Risk Factor of Oxidative Damage

Korpela, H 193

Plasma and Tissue-Free Amino Acids in the Developing Chick

Ng, L.T.; Pascaud, M 198

Prevalence of Obesity, Leanness and Anorexia nervosa in Japanese Boys and Girls Aged 12-14 Years

Ohzeki, T.; Hanaki, K; Motozumi, H.; Ishitani, N.; Matsuda-Ohtahara, H.; Sunaguchi, M.;

Shiraki, K 208

Non-Linear Relationship between Reduced Energy Intake and Rate of Weight Loss in

Rats

Macdonald, 1213

Vitamin D Status of Ambulatory and Nonambulatory Mentally Retarded Children with and without Carbamazepine Treatment

Lamberg-Allardt, C; Wilska, M.; Saraste, K.-L.; Grönlund, T 216

Contents V

Influence of Dietary Thermally Oxidized Soybean Oil on the Oxidative Status of Rats of

Different Ages

Corcos Benedetti, P.; Di Felice, M.; Gentili, V.; Tagliamonte, B.; Tomassi, G 221

Iron Deficiency in Growing Male Rats: A Cause Development of Cardiomyopathy

Petering, D.H.; Stemmer, K.L.; Lyman, S.; Krezoski, S.; Petering, H.G 232

Recovery Study in Mg-Deficient Rats Given an Organic Source of Mg

Aranda, P.; Lopez Frías, M.; Lopez Jurado, M.; Llopis, J.; Mataix, F.J.; Rivero, M.;

Urbano, G 244

Announcement 252

No. 5 Original Paper

Intersalt in Newfoundland and Labrador

Funke, E.; Schieffer, B.; Baikie, M.; Mohacsi, G.; Kirkland, C; Fodor, J.G.; Chockalin-

gam, A253

Effects of Anoxia and Low Free Fatty Acid on Myocardial Energy Metabolism in Streptozotocin-Diabetic Rats

Mokuda, O.; Sakamoto, Y.; İkeda, T.; Mashiba, H 259

Association of Pancreatic Biotinidase Activity and Intestinal Uptake of Biotin and Biocytin in Hamster and Rat

León-Del-Río, A.; Velazquez, A.; Vizcaino, G.; Robles-Díaz, G.; Gonzalez-Noriega, A. 266

Incidence of Biochemical Vitamin B6 Deficiency in Nigerian Adolescents 
Korede, $0 \quad 273$

Effect of Decreased Food Consumption during Iron Deficiency upon Growth Rate and Iron

Status Indicators in the Rat

Dhur, A.; Galán, P.; Hercberg, S 280

Influence of Different Types and Levels of Dietary Lipids on Liver Microsomal Mixed

Function Oxidase System in Rats

Saito, M.; Kubota-Shirao, M.; Kobatake, Y.; Yamaguchi, M 288

Effect of Methylxanthines on Lactional Performance of Rats

Hart, A.D.; Grimble, R.F 297

Steroid Pattern of Bile and Feces in Response to a Fruit-Enriched Diet in Hypercholester-

olemic Hamsters

Sable, R.; Sicart, R.; Berry, E 303

Skin Temperature and Energy Expenditure

Lanzola, E.; Tagliabue, A.; Cena, H 311

No. 6 Original Paper

Changes in Plasma Lipoprotein Concentrations and Compositions upon Feeding Cholesterol in

High- and Low-Responding Rhesus Monkeys

Myers, L.H.†; Bhattacharyya, A.K.; Eggen, D.A.; Strong, J.P 317

Influence of Dietary Fat on the Lipid Composition of Perirenal Adipose Tissue in

Rats

Valero-Garrido, D.; López-Frías, M.; Llopis, J.; López-Jurado, M 327

Diurnal Variation of Blood Ketone Bodies in Insulin-Dependent Diabetes mellitus and Noninsulin-Dependent Diabetes mellitus Patients: The Relationship to Serum C-Peptide Immunoreactivity and Free Insulin

Ubukata, E 333

VI Contents

Availability of Selenium in Dough and Biscuit in Comparison to Wheat Meal

Ciappellano, S.; Testolin, G.; Allegrini, M,; Porrini, M 343

Comparative Effects of Feeding Different Fats on Fatty Acid Composition of Major Indi

vidual Phospholipids of Rat Hearts

Ruiz-Gutierrez, V.; Molina, M.-T.; Vazquez, CM 350

Modifications of Abdominal Fat and Hepatic Insulin Clearance during Severe Caloric Restriction

Bosello, O.; Zamboni, M.; Armellini, F.; Zocca, I.; Bergamo Andreis, I.A.; Smacchia, C;

Milani, M.P.; Cominacini, L 359

Abstracts

Fourth Créteil Symposium on Lipids, Lipoproteins and Nutrition. Nutrition and Athero

sclerotic Plaque

Créteil, France, May 11, $1990 \quad 366$

Author Index 385

Subject Index 387 